DOI: https://doi.org/10.31392/NZ-npu-145.2019.8

УДК 378.091.3:373.3.011.3-051:613

Іенатенко С. А.

\title{
ОБҐРУНТУВАННЯ КРИТЕРІЇВ ТА РІВНІВ СФОРМОВАНОСТІ КУЛЬТУРИ БЕЗПЕКИ ЖИТТЄДІЯЛЬНОСТІ МАЙБУТНІХ УЧИТЕЛІВ МОЛОДШИХ КЛАСІВ
}

В статті висвітлено проблему формування культури безпеки життєдіяльності майбутніх учителів молодщих класів у процесі фахової підготовки. Проаналізовано стан розробленості проблеми формування культури безпеки життєдіяльності майбутніх учителів молодших класів у процесі фахової підготовки. Культура безпеки життєдіяльності виступає структурним компонентом базової культури особистості і невід'ємною частиною професійної культури (професійної компетентності) фахівия. Будучи компонентом професійної культури, яка не дається від народження, а формується і виховується в прочесі професійної підготовки фахівия, культура безпеки життєдіяльності майбутніх учителів молодщих класів виступає як об 'єкт педагогічного дослідження.

За результатами констатувального експерименту встановлено, що критеріальними показниками є професійно-якісні ознаки готовності до реалізації фахових компетентностей у процесі професійної діяльності. Визначення сформованості професійної компетентності майбутніх учителів молодших класів здійснюється за критеріями, які відображають сутність іï компонентів. Показники кожного критерію визначені нами на основі сутності відповідного компонента професійної компетентності майбутніх учителів молодших класів закладів вищої освіти.

Для ефективного впровадження технології формування культури безпеки життєдіяльності у майбутніх учителів початкової школи в прочесі фахової підготовки, здійснення діагностики досягнення результату компетентнісно-орієнтованого освітнього процесу з використанням критеріального підходу, визначено критерії: когнітивний, мотиваційно-ціннісний, практичний, рефлексивний, щьо мають відповідні якісні показники.

За результатами дослідження визначено стан вихідного рівня організачії професійної підготовки майбутніх учителів молодших класів, основні фактори, щзо впливають на формування професійно важливих особистісних якостей.

Ключові слова: учитель молодших класів, культура безпеки життєдіяльності, критерії, piвні.

Суспільні процеси, які відбуваються в Україні та у світі, зумовлюють необхідність модернізації системи освіти. Основні шляхи оновлення освіти у новому тисячолітті визначено в положеннях Національної стратегії розвитку освіти в Україні та інших державних нормативних документах, якими передбачається: відтворення інтелектуального потенціалу народу; забезпечення можливостей для саморозвитку людини; підготовка молоді до інтеграції в суспільство; професійна адаптація фрахівця в умовах трансформації суспільного устрою та фрормування його професійної мобільності й конкурентоспроможності. Зокрема, в документах висвітлені вимоги до якості професійної підготовки майбутніх учителів, котра має забезпечувати особистісно-професійний розвиток майбутнього вчителя на 
засадах особистісно спрямованої педагогічної інноватики [6; 7; 8].

Особлива суспільно значуща роль відводиться сучасному вчителю початкової школи. Успішне розв'язання суспільних завдань вимагає від особистості вибору стратегії неперервної освіти упродовж життя на основі саморозвитку, самовдосконалення та самоосвіти. Соціально-політичні та економічні проблеми зумовлюють сьогодні нові завдання і виклики, де важливим і необхідним стає вдосконалення змісту й форм освіти, викликане новими запитами щодо суспільної ролі вчителя, що викладені в концепції нової української школи [4; 5].

Зважаючи на вищезазначене, можна стверджувати, що сучасний випускник закладу вищої педагогічної освіти повинен мати розвинене сприйняття, розуміння і перетворення конкретної ситуації в системі "людиналюдина" та "людина-небезпека" в контексті своєї професійної діяльності. Поєднання знань про людину, як елемент середовища та про небезпеки, яке воно формує - має бути основою для створення систем попередження та захисту від них. Насамперед це ідентифікація типу ситуації, визначення фракторів, які зменшують рівень небезпеки та витрат від її розвитку, оцінка рівня ризику та прогнозування наслідків, дій для зменшення шкоди, а отже прийняття адекватного рішення та реалізація виробленого плану дій 3 подальшим запобіганням прояву подібних ситуацій [7; 9].

Сучасне освітнє середовище та його учасники потребують систем попередження та захисту він небезпек різного характеру, і тому вчитель має володіти відповідними знаннями, вміннями, та відповідно сформованим рівнем культури безпеки життєдіяльності. Це педагогічне явище, останнім часом привертає увагу в науковому просторі, де поряд з необхідністю формування профресійної компетентності, розглядається важливість створення здорового і безпечного освітнього простору закладів освіти. Отже, потребує аналізу проблема фрормування культури безпеки життєдіяльності майбутніх вчителів, вивчення педагогічного досвіду щодо вдосконалення фрахової підготовки в системі вищої освіти на засадах компетентнісного підходу.

Теоретичний аналіз проблеми особистісно-професійного розвитку та вивчення досвіду практикуючих вчителів початкової школи, професійної підготовки студентів у вищих навчальних закладах дають можливість визначити ряд суперечностей, які об'єктивно мають місце в педагогічній теорії та практиці [1; 12]:

- між вимогами суспільства до особистості вчителя та недостатнім рівнем його профресійної підготовки;

- між об’єктивними зростаючими вимогами педагогічної практики до рівня профресійної підготовки вчителя і здатністю випускників педагогічних 3ВО швидко та ефективно адаптуватися до реальних умов сучасного освітнього простору закладів загальної середньої освіти;

- між необхідністю постійного розвитку, саморозвитку, самовдосконалення майбутнього вчителя початкової школи та недостатньою опорою на реальні можливості самоосвіти, реальні можливості якісної самоосвіти, як умови досягнення більш високого рівня особистісно- 
профресійного розвитку.

Вищезазначені суперечності корелюють з сучасними тенденціями в освіті та особливостями оптимізації в контексті сучасних суспільних трансформацій (В. Подкопаєв, Н. Цимбалюк); фрундаментальними положеннями компетентнісного підходу як провідної методології сучасних транссрормаційних процесів в освіті, що ссрормульовано в дослідженнях Н. Бібік, Т. Байбари, І. Зимньої, В. Лозової, А. Маркової, О. Овчарук, О. Пометун, О. Савченко та ін.; особливостями модернізації системи вищої освіти, професійної підготовки майбутніх педагогів (А. Богуш, А. Горбатюк, О. Дубасенюк, І. Зязюна, В. Лугового, Н. Ничкало, О. Шапран та ін.); питаннями підготовки фахівців 3 безпеки життєдіяльності, управління безпекою та охороною праці (О. Дьоміна, Є. Желібо, Н. Заверуха, А. Матвєєв, О. Степанова, Д. Ступак та ін.).

Отже, доречно підкреслити особливий зв'язок між поняття культура, безпека життєдіяльності і педагогіка. Тобто неможливе пізнання без певного рівня культури, як не можна створити будь-який рівень культури без осягнення закономірностей об'єктивного світу, а основи цього зв'язку закладаються педагогікою в процесі виховання, освіти і навчання. Також, культура безпеки життєдіяльності як наука має виражену психолого-педагогічну спрямованість, оскільки основним об'єктом уваги і захисту від небезпек $є$ людина. В якості ознак безпеки людини і суспільства в психолого-педагогічній та науковометодологічній літературі називаються: стан середовища проживання, при якому з певною ймовірністю виключено заподіяння моральної, матеріального, економічної або фрізичної шкоди людині; відсутність шкідливих або небезпечних фракторів життєдіяльності; готовність людини до профілактики, подолання без шкоди, мінімізації (з мінімальними, тобто допустимими, втратами), усунення негативних наслідків впливу шкідливих і небезпечних фракторів життєдіяльності; міра захищеності організмів від внутрішніх і зовнішніх небезпек (засіб оцінки рівня ризику, захищеності); система заходів захисту людини і середовища проживання від небезпек (засіб забезпечення захищеності, профрілактики ризиків); стан, при якому ризик зведений до об'єктивного мінімуму; ступінь захищеності людини, її здатність забезпечувати особисту безпеку, свідомо знижуючи ступінь ризику, пов'язаного з діяльністю. Тому, в наш час широкого визнання набула вимога у вихованні молодого покоління на основі комплексного психолого-педагогічного підходу до формування культури безпеки життєдіяльності [2; 4; 9].

Мета статті полягає у висвітленні результатів дослідження зі змістового опису рівневих та критеріальних показників сформованості культури безпеки життєдіяльності майбутніх учителів молодших класів.

В нашому досліддженні ми розглядаємо модель навчально-методичної системи формування культури безпеки життєдіяльності майбутнього учителя початкової школи як науково обґрунтований проект реалізації системи дидактичних умов і педагогічних технологій компетентнісно орієнтованого та особистісно орієнтованого освітнього процесу професійної підготовки фрахівця, що включає профресійну підготовку у ЗВО за освітнім рівнем "бакалавр" 
спеціальність Початкова освіта.

Навчально-методична система формування культури безпеки життєдіяльності майбутніх учителів молодших класів зумовлена нормативною і варіативною частинами освітньої програми і визначає зміст професійної підготовки учителя початкової школи відповідно до освітнього рівня бакалавра 013 Початкова освіта. Вимоги до змісту, обсягу відповідно до освітнього рівня встановлено також освітньою програмою. Отже, реалізація блоку компетентностей по фрормуванню культури безпеки життєдіяльності майбутніх учителів початкової школи також визначається нормативними і варіативними частинами освітньо-кваліфрікаційних характеристик, освітньо-професійної програми, засобів діагностики якості вищої освіти галузевого стандарту вищої освіти та стандарту вищої освіти 3ВО. Формування культури безпеки життєдіяльності на основі відповідних блоків компетентностей забезпечує необхідний рівень реалізації фрахових функцій у майбутній професійній діяльності. Компетентності визначається освітньо-кваліфікаційними вимогами, які обумовлюють кінцевий результат етапу навчання у закладі вищої освіти за освітнім рівнем бакалавра 013 Початкова освіта [7; 10].

За результатами нашого дослідження встановлено, що критеріальними показниками $є$ професійно-якісні ознаки готовності до реалізації фахових компетентностей у процесі профресійної діяльності, профресійного розвитку і розвитку здібностей майбутнього учителя молодших класів, здатності до самоконтролю, самоаналізу, саморегуляції, самовдосконалення та самооцінки у здійсненні науково-педагогічної діяльності. Визначено відповідні рівні сорормованості професійної компетентності та культури безпеки життєдіяльності майбутнього учителя молодших класів: високий (творчий); достатній (базовий); середній (функціональний); низький (критичний).

Отже, на нашу думку, проаналізовані підходи щодо визначення рівнів сфрормованості професійної компетентності у майбутніх фахівців мають досить багато загальних позицій. За результатами нашого дослідження у процесі констатувального експерименту та 3 урахуванням специфіки профресійної діяльності майбутніх учителів молодших класів закладів вищої освіти нами визначеноі рівні сформованості професійної компетентності: високий (творчий) рівень; достатній (базовий) рівень; середній (функціональний) рівень; низький (критичний) рівень. Визначені рівні сформованості зумовлені тим, що професійна компетентність майбутніх учителів молодших класів спрямована в першу чергу на збереження життя, здоров'я і працездатності дитини в освітньому процесі та фрормування готовності випускників до реалізації фахових компетенцій, у тому числі й науково-педагогічної, керування виробничою практикою, прийняття рішень в екстремальних виробничих ситуаціях та ін.

Теоретичне обгрунтування змістових характеристик рівнів сфрормованості культури безпеки життєіяльності майбутніх учителів молодших класів ми здійснили, беручи за основу передовий вітчизняний та узагальнений зарубіжний науково-педагогічний досвід [3, 5, 13].

В розробленій нами моделі рівні сфрормованості культури безпеки 
життєдіяльності майбутніх учителів молодших класів ми розглядаємо в такому трактуванні:

Високий (творчий) рівень. Студенти з високим рівнем виявляють рішучість, здатність до обдуманого управління ризиком, які супроводжуються високою активністю та впевненістю особистості у своїх діях. Відповідно до практичного критерію студенти мають сформовану готовність до реалізації фрахових компетентностей учителя молодших класів. Цілеспрямовано займаються самоосвітою, самовихованням, що сприяє їх мобільності та конкурентоспроможності на ринку праці. Вміють приймати ефрективні рішення й готові нести відповідальність за їх наслідки. Відповідно мотиваційноособистісного критерію характеризуються професійною мотивацією, профресійною спрямованістю науково-педагогічної діяльності та профресійно важливими якостями і здібностями майбутнього викладача безпеки життєдіяльності та охорони праці: в своїх діях ініціативні, рішучі й самостійні, мають розвинені особистісні та профресійно важливі якості, серед яких чільне місце займає лідерство, відповідальність, авторитетність, готовність здійснювати науково-педагогічну діяльність у закладі вищої освіти. Відповідно до когнітивного критерію студенти володіють глибокими і системними науковотеоретичними та науково-практичними знаннями в галузі безпеки життєдіяльності та охорони праці, здатні вдосконалювати професійні знання шляхом самоосвіти, активно засвоюючи нову інформацію, систематизують їі, використовуючи новітні досягнення науки і техніки. Відповідно до ресрлексивного критерію характеризуються здатністю систематично профресійно розвиватися і зростати, аналізувати власний педагогічний досвід та вдосконалювати науково-педагогічну діяльність на основі самоконтролю, саморегуляції, самовдосконалення та самооцінки у процесі науковопедагогічної діяльності у закладі вищої освіти.

Достатній (базовий) рівень. Студенти базового рівня, зазвичай, активні, впевнені та ініціативні. Їх рішучість детермінована пізнавальними можливостями. Мають достатній рівень готовності до реалізації фрахових компетентностей, готові до виконання нових завдань, розуміють їх суть, проте відповідно до практичного критерію при необхідності застосувати творчий, продуктивний підхід у їх вирішенні, заручаються підтримкою інших. Професійно важливі якості мають системний, однак недостатньо яскравий прояв. Простежується мотивація до лідерства у вирішенні профресійних завдань, а також мотивація здійснювати науково-педагогічну діяльність у закладі вищої освіти. Студенти володіють достатніми знаннями в галузі безпеки життєдіяльності та охорони праці відповідно до когнітивного критерію і високо розвинуті комунікативні здібності. Нову інформацію сприймають конструктивно. Відповідно до рефрлексивного критерію можуть аналізувати профресійний досвід, використовувати у профресійній діяльності навички самоконтролю, саморегуляції та самооцінки.

Середній (функціональний) рівень. Студентам середнього рівня притаманна зайва й безпідставна самовпевненість, що гальмує процес їх саморозвитку та самовдосконалення. Готовність до управління ризиком 
супроводжується діями навмання в процесі здійснення яких особистість сподівається на позитивний результат, маючи не достатній рівень готовності до реалізації фахових компетентностей. Однак студенти готові до виконання типових, професійних завдань і не завжди досягають ефективного результату у вирішенні нестандартних профресійних ситуацій відповідно до практичного критерію. Ситуативно мають утруднення у прийнятті рішень, щодо безпеки в межах своїх повноважень, тому часто заручаються підтримкою інших. Цінують добре продумані та обґрунтовані рішення. За якісними характеристиками мотиваційно-особистісного критерію характеризуються недостатньою сорормованістю мотивації до науково-педагогічної діяльності 3 безпеки життєдіяльності та охорони праці. При необхідності швидко діяти виявляють нерішучість, тому активністю не вирізняються, нерішучі у готовності здійснювати науково-педагогічну діяльність у закладі вищої освіти. Відповідно когнітивного критерію не завжди застосовують професійні знання, оскільки вони не системні. Нову інформацію сприймають пасивно. Відповідно до рефлексивного критерію почуваються невпевнено у ситуаціях, що сприяють профресійному саморозвитку та самоаналізу утруднень навчання і практичної діяльності.

Низький (критичний) рівень. У студентів цього рівня зазвичай, готовність до ризику помітно виражена, що призводить до не обміркованих вчинків. У виконанні завдань професійного спрямування виявляють невпевненість у своїх діях, побоювання результату невдачі гальмує їх активність, що супроводжується безініціативністю, байдужістю та безвідповідальністю, значними утрудненнями у професійній готовності до реалізації фахових компетентностей відповідно до практичного критерію. Науково-теоретичні та науково-практичні знання $\epsilon$ поверхневими та безсистемними. Нову інформацію сприймають неохоче, досить часто байдуже. Не здатні до самоосвіти, самовиховання, що пояснюється відсутністю мотивації професійно розвиватись, працювати за професією в майбутньому та демотивацією здійснювати науково-педагогічну діяльність у закладі вищої освіти. Не здатні до самоаналізу, а також до саморегуляції у процесі навчання $[1 ; 3 ; 11]$.

Аналіз науково-педагогічої літератуи дозволяє виявити загальні вимоги до обґрунтування й визначення критеріїв, які зводяться до наступного:

- критерії повинні відображати основні закономірності функціонування і розвитку аналізованого явища;

- за допомогою критеріїв повинні встановлюватися зв'язки між всіма компонентами аналізованого явища;

- критерії повинні розкриватися через показники, за якими можна судити про більший або менший ступінь вираженості даного критерію;

- критерії повинні відображати динаміку вимірюваної якості в часі та просторі;

- якісні показники повинні виступати в єдності 3 кількісними та доповнювати один одного [2, 12].

Отже, критерії розкриваються через систему показників, зміна яких має 
виявити ступінь успішності навчального процессу, проте більшість дослідників всі критерії профресійної компетентності поділяють на дві групи, зокрема об'єктивні критерії (ті, що характеризують відповідність спеціаліста вимогам профресії). Серед них виокремлюються:

- критерії, які належать до нормативних показників успішності реалізації діяльності (зовнішні результативні): продуктивність, якість, надійність, становище в колективі, у системі міжособистісних відносин, соціальний статус;

- критерії, які характеризують рівень професійної кваліфікації об’єкта праці, розвитку професійно важливих якостей (внутрішні змістові), а також характер діяльності, що здійснюється окремим фрахівцем на предмет відповідності їі технологічної сторони соціально прийнятним способам і вимогам професії (процесуальні) [9, с. 160-165].

Визначення сорормованості професійної компетентності майбутніх учителів молодших класів закладів здійснюється за критеріями, які відображають сутність її компонентів. Показники кожного критерію визначені нами на основі сутності відповідного компонента професійної компетентності майбутніх учителів молодших класів закладів закладів вищої освіти.

Для ефективного впровадження технології фрормування культури безпеки життєдіяльності у майбутніх учителів початкової школи в процесі фрахової підготовки, здійснення діагностики досягнення результату компетентнісноорієнтованого освітнього процесу - сфрормованості культури безпеки життєдіяльності з використанням критеріального підходу, у моделі визначено критерії, що мають відповідні якісні показники.

Когнітивний критерій визначається рівенем сорормованих компетентностей, обумовлених освітньою програмою спеціальності 013 Початкова освіта та має показники: оволодіння професійно-значущими знаннями (фундаментальними, спеціальними, психолого-педагогічними, управлінськими, науково-методичними, предметними, технологічними, проектувальними та ін.);

Мотиваційно-ціннісний критерій має такі показники: усвідомлення професійної необхідності застосування теоретичних і практичних знань для вирішення завдань майбутньої професійної діяльності; прагнення до здорових міжособистісних взаємин в робочих мікрогрупах; сорормоване відповідальноціннісне ставлення до життя і здоров'я дітей як до найвищої цінності суспільства; ціннісно-мотивована спрямованість до професійної реалізації у профрілактично-освітній діяльності для зміцнення і збереження життя і здоров'я молодших школярів; професійна мотивація до удосконалення фахового рівня, як особистісного творчого розвитку та самореалізації в майбутній педагогічній діяльності, усвідомлене ставлення до компетентнісно орієнтованої професійної освіти і професійного розвитку упродовж всього життя.

Практичний критерій визначається готовністю до реалізації сформованих компетентностей, обумовлених освівтньою програмою спеціальності 013 Початкова освіта та ступенем володіння сучасними технологіями навчання основ охорони життя і здоров'я у початковій школі, визначається показниками щодо ефективної реалізації теоретичних і 
практичних знань через діяльнісно-ефективні уміння вирішувати життєвонеобхідні ситуації з охорони життя і здоров'я, соціально обумовлені та необхідні для майбутньої професійної діяльності.

Рефрлексивний критерій визначається готовністю майбутнього учителя молодших класів до поетапного моніторингу якості компетентнісно орієнтованого процесу професійної підготовки та самооцінки, саморегуляції, цілеспрямованості удосконалення рівня сфрормованості культури безпеки життєдіяльності [5; 12].

Висновок. За результатами дослідження встановлено, що критеріальними показниками $€$ професійно-якісні ознаки готовності до реалізації фахових компетентностей у процесі професійної діяльності. Визначення сорормованості професійної компетентності майбутніх учителів молодших класів здійснюється за критеріями, які відображають сутність її компонентів. Показники кожного критерію визначені нами на основі сутності відповідного компонента професійної компетентності майбутніх учителів молодших класів закладів вищої освіти.

Сорормованість культура безпеки життєдіяльності як складової профресійної компетентності майбутніх учителів початкової школи ми розглядали в безпосередньому взаємозв'язку 3 майбутньою професійнопедагогічною діяльністю, як динамічну здатність (готовність) студентів до вирішення професійних завдань початкової загальної освіти, що поєднує мотиваційно-ціннісний, когнітивно-діяльнісний та проектувально- технологічний компоненти.

Результати дослідження сорормованості культури безпеки життєдіяльності майбутніх учителів молодших класів сприятимуть розробці і впровадженню навчально-методичної системи формування культури безпеки життєдіяльності майбутніх учителів початкової школи в процесі професійної підготовки у закладі вищої освіти, що є науковою основою розвитку ноосферного мислення, через становлення психології творчої інфрормаційної діяльності, започаткування і розвитку педагогічної майстерності, програмування та абстрагування продуктивної розвивальної діяльності 3 використанням інноваційних технологій навчання та виховання, якими необхідно наповнити зміст освітнього процесу професійної підготовки майбутнього учителя молодших класів.

\section{Використана література:}

1. Бартків О. Готовність педагога до інноваційної діяльності. Проблеми підготовки сучасного вчителя. 2010. № 1. С. 52-58.

2. Волощук І. С. Педагогічне дослідження. Київ : Інформаційні системи, 2009. 390 с.

3. Дубасенюк О. А. Професійна педагогічна освіта: інноваційні технології та методики : монографія. Житомир : ЖДУ ім. І. Франка, 2009. 504 с.

4. Михайлишин Р. Професійна готовність педагога до інноваційної діяльності: якісний аспект. Вісник Львівського університету. Серія педагогічна. 2016. Вип. 31. С. 11-18

5. Міненок А.О. Професійний саморозвиток майбутнього вчителя початкової школи : теорія i практика : монографія. Київ : СПД Нестроєвий А.І., 2015. 412 с. 
6. Національна стратегія розвитку освіти в Україні на період до 2021 року [Електронний ресурс]. Законодавство України. URL : http://zakon4.rada.gov.ua/laws/show/344/2013 (дата звернення 4.10.2019)

7. Нова українська школа. Концептуальні засади реформування середньої школи. [Електронний pecypc]. Міністерство освіти і науки України. URL : https://mon.gov.ua/ua/tag/nova-ukrainska-shkola (дата звернення 28.10.2019).

8. Про затвердження Концепції розвитку педагогічної освіти [Електронний ресурс]. Міністерство освіти і науки України. URL: https://mon.gov.ua/ua/npa/pro-zatverdzhennya-koncepciyi-rozvitkupedagogichnoyi-osviti (дата звернення: 10.10.2019)

9. Ступак Д. Є. Методичні основи формування готовності до реалізації фахових компетенцій викладача галузі безпеки життєдіяльності та охорони праці ВНЗ. Проблеми сучасної педагогічної освіти. Ялта, 2014. Вип. 42. Ч. І. С. 160-165.

10. Tuning Education Structures in Europe. [Електронний ресурс] - Режим доступу: http://tuning.unideusto.org. - 2008.

11. Фіцула М. М. Педагогіка : Навчальний посібник для студентів вищих педагогічних закладів освіти. Київ : Видавничий центр “Академія”, 2002. 528 с.

12. Щербей У. В. Педагогічні умови реалізації міжпредметних зв'язків у професійній підготовці майбутніх учителів початкових класів : автореф. дис. ... канд. пед. наук. Київ, 2016. 21 с.

13. Юсупова М.Ф. Застосування нових інформаційних технологій в графічній підготовці студентів вищих навчальних закладів: автореферат дисертації на здобуття наукового ступеня кандидата педагогічних наук: 13.00.02. Київ : Нац. пед. ун-т ім. М. П. Драгоманова, 2002. 19 с.

\section{References:}

[1] Bartkiv, O. (2010). Hotovnist pedahoha do innovatsiinoi diialnosti. Problemy pidhotovky suchasnoho vchytelia. [Teacher's readiness to innovative activity]. Problemy pidhotovky suchasnoho vchytelia. Problems of modern teacher training, 1, 52-58.

[2] Voloshchuk, I. S. (2009). Pedahohichne doslidzhennia. [Pedagogical research]. Kyiv, Ukraine: Information Systems.

[3] Dubaseniuk, O. A. (2009). Profesiina pedahohichna osvita: innovatsiini tekhnolohii ta metodyky: monohrafiia. [Professional pedagogical education: innovative technologies and methods: monograph]. Zhytomyr, Ukraine : Zhytomyr National University.

[4] Mykhailyshyn, R. (2016). Profesiina hotovnist pedahoha do innovatsiinoi diialnosti : yakisnyi aspekt. [Professional readiness of the teacher to innovative activity: qualitative aspect]. Visnyk Lvivskoho universytetu. Seriia pedahohichna. Visnyk of Lviv University. Series Pedagogics, issue 31, 11-18.

[5] Minenok A. O. (2015) Profesijnyj samorozvytok majbutnogo vchytelya pochatkovoyi shkoly: teoriya i praktyka : monografiia.[Professional individual development of future teacher of initial school: is a theory of i practical worker : monograph]. Kyiv : of SPD of Nestroievi A.I.

[6] Natsionalna stratehiia rozvytku osvity v Ukraini na period do 2021 roku [National Strategy for the Development of Education in Ukraine until 2021]. (2013, July). Zakonodavstvo Ukrainy - Legislation of Ukraine. Retrieved from http://zakon4.rada.gov.ua/laws/show/344/2013.

[7] Nova ukrainska shkola. Kontseptualni zasady reformuvannia serednoi shkoly [New Ukrainian school. Conceptual principles of reformation of high school]. (2019, october 28) Ministerstvo osvity i nauky Ukrajiny - Ministry of Education and Science of Ukraine. Retrieved from https://mon.gov.ua/ua/tag/nova-ukrainska-shkola

[8] Pro zatverdzhennia Kontseptsii rozvytku pedahohichnoi osvity [Approval of the Concept of development of pedagogical education]. Ministerstvo osvity i nauky Ukrainy - Ministry of education and science of Ukraine. Retrieved from https://mon.gov.ua/ua/npa/pro-zatverdzhennya-koncepciyi-rozvitkupedagogichnoyi-osviti.

[9] Stupak D. Ye. (2014) metodychni osnovy formuvannya gotovnosti do realizaciyi faxovyx kompetencij vykladacha galuzi bezpeky zhyttyediyalnosti ta oxorony praci VNZ [Methodical bases of forming of readiness to realization of professional competenses of teacher of industry of safety of vital functions and labour of institution of higher learning protection. Problems of modern pedagogical education]. Yalta, issue $42,160-165$.

[10] Tuning Education Structures in Europe. [Електронний ресурс]. Режим доступу: http://tuning.unideusto.org. - 2008 . 
[11] Fitsula, M. M. (2002). Pedahohika: Navchalnyi posibnyk dlia studentiv vyshchykh pedahohichnykh zakladiv osvity [Pedagogy: textbook of students of higher pedagogical educational institutions]. Kyiv, Ukraine : Vydavnychyi tsentr "Akademiia".

[12] Shcherbei, U. V. (2016). Pedahohichni umovy realizatsii mizhpredmetnykh zviazkiv u profesiinii pidhotovtsi maibutnikh uchyteliv pochatkovykh klasiv [Pedagogical conditions of implementation of interdisciplinary connections in the training of primary school teachers]. Extended abstract of candidate's thesis. Kyiv, Ukraine : DKS Tsentr.

[13] Yusupova, M. F. (2002). Zastosuvannia novykh informatsiinykh tekhnolohii v hrafichnii pidhotovtsi studentiv vyshchykh navchalnykh zakladiv. [Application of new information technologies in graphic preparation of students of higher educational institutions] Extended abstract of candidate's thesis. Kiev. Ukraine: National ped Untitled M. P. Drahomanov.

ИГНАТЕНко С.А. Обоснование критериев и уровней сформированности культуры безопасности жизнедеятельности будущих учителей младиих классов.

В статье освещена проблема формирования культуры безопасности жизнедеятельности будуших учителей младших классов в процессе профессиональной подготовки. Проанализировано состояние разработанности проблемь формирования культуры безопасности жизнедеятельности будущих учителей младших классов в процессе профессиональной подготовки. Культура безопасности жизнедеятельности выступает структурным компонентом базовой культуры личности и неотъемлемой частью профессиональной культуры (профессиональной компетентности) специалиста. Будучи компонентом профессиональной культуры, которая не дается от рождения, а формируется и воспитывается в прочессе профессиональной подготовки специалиста, культура безопасности жизнедеятельности будущих учителей младших классов выступает как объект педагогического исследования.

По результатам констатирующего эксперимента установлено, что критериальными показателями являются профессионально-качественные признаки готовности к реализации профессиональных компетенций в процессе профессиональной деятельности. Определение сформированности профессиональной компетентности будущих учителей младших классов осуществляется по критериям, которые отражают сущность ее компонентов. Показатели каждого критерия определень нами на основе сущности соответствующего компонента профессиональной компетентности будущих учителей младиих классов в высших учебных заведениях.

Для эффективного внедрения технологии формирования культуры безопасности жизнедеятельности у будуших учителей начальной школь в проиессе профессиональной подготовки, осуществления диагностики достижения результата компетентноориентированного образовательного прочесса с использованием критериального подхода, определены критерии: когнитивныгй, мотивационно-цеенностный, практичный, рефлексивный, которые имеют соответствуюшие качественные показатели.

По результатам исследования определено состояние исходного уровня организации профессиональной подготовки будущих учителей начальных классов, основные факторы, влияющие на формирование профессионально важных личностных качеств.

Ключевые слова: учитель младших классов, культура безопасности жизнедеятельности, критерии, уровни.

IHNATENKo S. A. Justification of the criteria and levels of life safety culture development of future primary school teachers.

The article highlights the problem of the life safety culture development of future primary school teachers in the process of professional training. It analyses the state of elaboration of the problem of the life safety culture development in the process of professional training. Life safety culture is a structural component of basic education and is an integral part of the professional culture (professional competence) of the future specialist. Being a component of professional culture, which is 
not given from birth, but that is formed and developed in the process of professional training, the life safety culture of future primary school teachers presents as an object of pedagogical research.

According to the results of the experiment, it was found that the criterion measures are of professional-quality signs of readiness to realization of professional competences in the process of professional activity. The determination of the professional competence development of future primary school teachers is carried out according to criteria that reflect the essence of its components. The indicators of each criterion are determined by us on the basis of the essence of the corresponding component of professional competence of future primary school teachers in higher educational institutions.

For the effective implementation of the technology of forming a culture of life safety for future primary school teachers in the process of vocational training, diagnosing the achievement of the result of a competen-oriented educational process using a criteria-based approach, the following criteria are defined: cognitive, motivational-valueable, practical, reflective, which have corresponding qualitative indicators

According to the results of the research, it was determined the initial level of organization of professional training of future primary school teachers, the main factors affecting the development of professionally important personal qualities.

Keywords: primary school teacher, life safety culture, criteria, levels.

DOI: https://doi.org/10.31392/NZ-npu-145.2019.9

УДК 37.014.3:37.011.3-051

Матвієнко О.В.

\section{АКТУАЛЬНІ ПРОБЛЕМИ \\ ФОРМУВАННЯ ПЕДАГОГІЧНОЇ ПОЗИЦІЇ ВЧИТЕЛЯ В УМОВАХ РЕФОРМУВАННЯ СИСТЕМИ ОСВІТИ}

У статті автор наводить аналіз вимог сучасної освітньої політики до професіоналізму вчителя $і$ теоретично обтрунтовує особливості формування педагогічної позиції вчителя як показника його професіоналізму у взаємодії з учнем. Проаналізувавши психолого-педагогічну літературу з теми дослідження, з'ясовано, щзо на сучасному етапі реформування системи освіти, одним з орієнтирів стає оновлення змісту професійної діяльності вчителя.

Ключові слова: професіоналізм, педагогічна позиція, державний стандарт, вчитель, педагогічна освіта, педагогічна взаємодія, освітня політика.

На сучасному етапі розбудови незалежної української держави питання становлення і розвитку педагогічної освіти стають дедалі суттєвішими для визначення стратегії й тактики входження до нового європейського освітнього простору. Адже сьогодні Україна переживає складний період рефрормаційних перетворень у галузі освіти, намагаючись вийти на рівень світових освітніх стандартів. Положення законів України “Про освіту" (2017р.), "Про вищу освіту" (2014р.), "Національної стратегії розвитку освіти в Україні на період до 2021 року" (2013 р.) та Концепції реалізації державної політики у сорері реформування загальної середньої освіти "Нова українська школа" на період 